\title{
CORRECTION
}

\section{Correction: Systemic inflammation scores correlate with survival prognosis in patients with newly diagnosed brain metastases}

Angelika M. Starzer, Ariane Steindl, Maximilian J. Mair (D), Carola Deischinger, Anika Simonovska, Georg Widhalm, Brigitte Gatterbauer, Karin Dieckmann, Gerwin Heller (D), Matthias Preusser and Anna S. Berghoff (D)

(c) The Author(s), under exclusive licence to Springer Nature Limited 2022

British Journal of Cancer (2022) 126:968; https://doi.org/10.1038/s41416-022-01722-9

Correction to: British Journal of Cancer https://doi.org/10.1038/ s41416-020-01254-0, published online 21 January 2021

The copyright holder for this article was incorrectly given in the HTML version as 'The Author(s), under exclusive licence to The
Author(s), under exclusive licence to the International Pediatric Research Foundation, Inc' but should have been 'The Author(s), under exclusive licence to the International Pediatric Research Foundation, Inc'. The PDF version was unaffected. 